Tropical Journal of Pharmaceutical Research January 2016; 15 (1): 47-53

ISSN: $1596-5996$ (print); 1596-9827 (electronic)

(C) Pharmacotherapy Group, Faculty of Pharmacy, University of Benin, Benin City, 300001 Nigeria.

All rights reserved.

Available online at http://www.tjpr.org

Original Research Article

http://dx.doi.org/10.4314/tjpr.v15i1.7

\title{
Aldehyde Dehydrogenase 1 and Raf Kinase Inhibitor Protein Expression Defines the Proliferative Nature of Cervical Cancer Stem Cells
}

\author{
Xiang-Xiu Sun ${ }^{1}$, Qing-Shan $\mathrm{Ma}^{2}$, Tian-Feng Liu ${ }^{1}$, Ying Chen ${ }^{1}$, Yan Dong ${ }^{1}$ and \\ Lin-Lin Zhang ${ }^{1 *}$ \\ ${ }^{1}$ Department of Gynaecology and Obstetrics, ${ }^{2}$ Department of Oncology, Linyi People's Hospital, Linyi, Shandong, 276000, \\ China
}

*For correspondence: Email: zhanglingling49@gmail.com; Tel/Fax: 0086-539-8216079

Received: 4 August 2015

Revised accepted: 1 December 2015

\begin{abstract}
Purpose: To determine the differences in response following the use of aldehyde dehydrogenase 1 (ALDH1) and Raf kinase inhibitor protein (RKIP) as cervical cancer stem cell markers.

Methods: To evaluate the cancer stem cell markers, a mouse model with low and high grade cervical cancer was developed and studied by histological examination. Immunohistochemical and Western blotting techniques were employed to study the expression profiles of ALDH1 and RKIP. The specificity of Sox2 that determines cancer stem cells served as control to validate ALDH1 and RKIP expressions. Results: Histological data helped to differentiate low from high grade cervical cancer. The results from immunohistochemistry show increased pattern of Sox2 expression as tumour progresses. Similarly, $A L D H 1$, a protein that positively regulates stem cells shows mild expression in low grade cervical tumour, but positive signals are more amplified in an aggressive stage of tumour condition when compared with Sox2. The expression study with RKIP, a protein that negatively regulates stem cells, interestingly defines the higher expression in low grade cervical cancer to regulate the tumour, but shows little or no very mild expression in the aggressive stage of tumour. All the data obtained show a statistically significant value of $p<0.05$. The results with Immunohistochemistry were further validated using the western blotting analysis and it also confirms the similar results.

Conclusion: ALDH1 and RKIP marker in association correlation with Sox2 aids in defining the proliferative ability of cervical cancer stem cells and also to validate them in initial and advanced stages of cervical cancer.
\end{abstract}

Keywords: Cervical cancer, ALDH1, BALB/c-nu/nu, HeLa cells, RKIP, Sox2

\begin{abstract}
Tropical Journal of Pharmaceutical Research is indexed by Science Citation Index (SciSearch), Scopus, International Pharmaceutical Abstract, Chemical Abstracts, Embase, Index Copernicus, EBSCO, African Index Medicus, JournalSeek, Journal Citation Reports/Science Edition, Directory of Open Access Journals (DOAJ), African Journal Online, Bioline International, Open-J-Gate and Pharmacy Abstracts
\end{abstract}

\section{INTRODUCTION}

On a global level, cervical cancer is reported to be the fourth most common cancer among women population [1]. Yearly, almost 470,000 new cases are diagnosed with a malignant form of cervical cancer and 233,000 death cases are reported every year [2]. Chemotherapy, radiotherapy and surgery are handful to improve the survival of patients with cervical carcinoma [3], but in approximately $35 \%$ of cases, after initial improvement, the disease starts to worsen within the time range of three years [4]. The recurrence of the disease implies that the resistance of cervical cancer cells or cancer stem cells that still remain after treatment gets triggered before their re-emergence. Cancer stem cells possess the ability of self-renewal and 
differentiation to form matured cancer cells that are linked with tumour initiation, metastasis and recurrence [5]. The role of cancer stem cells was first identified in leukemias and later, were identified in solid tumours like brain [6], colon [7] and also in cervical cancers [8].

The field research area of cancer stem cells is a newly developing field and identifying these cells is tricky at present. Most of the normal stem cell markers cannot effectively guide in the specific identification of cancer stem cells because it emerged from a specific mutation that takes place in stem cell population. Comparing the novel markers that show the under-expression and up-regulation in cancerous activity, helps to refine and identify the proliferative cancer stem cells. Aldehyde dehydrogenases (ALDH) are $\mathrm{NAD}(\mathrm{P})^{+}$dependent detoxifying enzymes that determines cell survival ability was initially identified established as a stem cell marker in haematopoietic stem cells [9]. A high expression of ALDH can also used to distinguish neural stem cells [10]. The ALDH activity can also be a useful cancer stem cell marker because it determines metastasis and cell survival [11]. It is successfully used as a stem cell marker for many cancer types including cervical cancer [12]. The current study defines the role of ALDH as a cancer stem cell marker that vary among different cancer types and also within the same tumour cell lines [13]. The Raf kinase inhibitor protein (RKIP) was identified as a metastasis suppressor in many tumour types like in prostate cancer [14], colorectal cancer [15] and in cervical cancer [16]. But these markers suffer from poor prognosis in cervical cancer, as well as in other cancer types $[17,18]$. In this paper, we have selected a pair of over-expression and underexpression markers namely ALDH and RKIP, to understand the proliferative nature of cancer stem cells in a cervical cancer mice model so that a precise identification is achieved.

\section{EXPERIMENTAL}

\section{Animals}

The animals were handled following the guidelines for using experimental animals [19]. For experimental purpose, the female strain of nude athymic mice (BALB/c-nu/nu), aged 8 weeks was uniformly chosen. The HeLa cells grown in a serum free medium were dissociated to obtain individual cells. The cells were then resuspended in $100 \mu \mathrm{l}$ of FBS and growth factorfree DMEM at a cell density of $1 \times 10^{5}$ cells [8]. The obtained cells were then injected subcutaneously into the left and right flanks [8]. The injected athymic mice were monitored and provided water, feed and maintained in dust free laboratory condition [20] for eight weeks. The tumour samples were collected in initial development stage of the tumour initiation (on the 4th week) and in the aggressive stage of the tumour condition (on the 8th week) by scarifying the mice using standard procedure [21].

\section{Immunohistochemistry}

For performing immunohistochemistry, the tissue sections were initially fixed in $10 \%$ formalin solution, and after dehydration and clearing, the tissues were paraffin embedded. The tissue sections were then subjected to microtome sectioning of size $6 \mu \mathrm{m}$. The sections were then carefully placed on glass slides and were deparaffinized and then rehydrated. The endogenous peroxidase activity was blocked by immersing the sections in freshly prepared $10 \%$ $\mathrm{H}_{2} \mathrm{O}_{2}$ and $10 \%$ Methanol with 1X PBS for 20 mins. Trypsin treatment $(0.1 \%$ trypsin in $0.1 \%$ $\mathrm{CaCl}_{2}$ ) was maintained for 10 min to cleave the protein cross link, so as to assess the antigen and epitope. The non-specific antigens were blocked using $4 \%$ of BSA and then were incubated with suitable primary antibody (AntiALDH1 antibody, Abcam (EP1933Y); Anti-Sox2 antibody, Abcam (ab92494); anti-RKIP Antibody, Santa cruz (SC-28837) overnight at $4{ }^{\circ} \mathrm{C}$. After incubation, the sections were thoroughly washed with 1X PBS and latter incubated with a suitable secondary antibody for $30 \mathrm{~min}$ at room temperature. After washing the non-specific binding, the sections were stained with $D A B$ (diaminobenzidine) Kit.

\section{Western blot analysis}

The samples from normal tissue, initial stage and samples from advanced stages of cervical cancer were dissected and the protein samples were prepared from the cell lysate. The cellular proteins were resolved in $12 \%$ SDS-PAGE gel by following the protocol as described [22]. The protein in the gel was then transferred to the PVDF membrane. After blocking the membrane overnight at $4 \stackrel{\circ}{\circ}$, they were incubated with an appropriate dilution of the primary antibody (AntiALDH1 antibody, Abcam (EP1933Y); Anti-Sox2 antibody, Abcam (ab92494); anti-RKIP Antibody, Santa cruz (sc-28837) according to the manufacturer's instruction. The membranes were then incubated with the suitable secondary antibody of dilution concentration (1:3000). After following washing, the membrane was developed to obtain the signal. 


\section{Statistical analysis}

The results are presented as mean \pm standard deviation (SD) and were analysed by analysis of variance (ANOVA). The software used for the analysis was Microsoft Office Excel 2007. $P<$ 0.05 was considered statistically significant.

\section{RESULTS}

\section{Mice model to study cervical cancer}

Studies carried out with the cell lines of cervical cancer to find out new markers of cancer stem cells varies in result even within a particular tumour cell line and it requires different understanding [13]. Therefore, studying and assessing the cancer stem cells markers in an identical animal model was more valuable. Cervical cancer was developed in the in vivo model of mice as described in the materials and methods.

After injection with HeLa cells, the mice developed the initial stage of cervical cancer on the 4th week and more advanced stages of the tumour on the 8th week of post injection as visualized in the histological sections (Fig 1). The histology of the normal cervical tissue sections shows the regular arrangement of a cellular pattern with less cell density (Fig 1A). As the tumour starts to developed, the proliferative cells starts to increase during the initial stage on the 4th week (Fig 1B) and reach its maximum during the advance stage of cervical cancer (Fig 1C).

\section{Comparing Sox 2 expression with ALDH and RKIP}

The Sox2 expression was tightly correlated linked with the progression of many human malignancies [23] and it was effectively used in breast cancer and glioblastoma as a cancer stem cell marker [24,25]. The correlation association between Sox2 expression with cervical cancer stem cell population is also well documented [23]. Another interesting correlation is that the depletion in Sox2 expression is linked with the reduction of the transformational properties of the cell [26]. In this study, we used the Sox2 as a standard maker to determine the role of ALDH and RKIP in determining the proliferation ability of cervical cancer stem cells.

Immunohistochemical analysis of normal cervical tissue shows limited positive cells for Sox 2 expression (Fig 2A). As the tumour progressed, the population of Sox2 positive cells shows concurrent increase in number by the 4th week of the initial stage of cervical cancer (Fig 2B) and their expression reached its maximum on the 8th week of the advanced stage of the cervical cancer $(p<0.05)$ (Fig 2C). Similarly, the ALDH1 expression also shows high-regulated expression as the tumour progressed (Fig 2D-F).

The proposition of ALDH1 positive cells were limited in normal tissue (Fig 2D) and their expression starts to increase in the primary stage of cancer (Fig 2E).
A

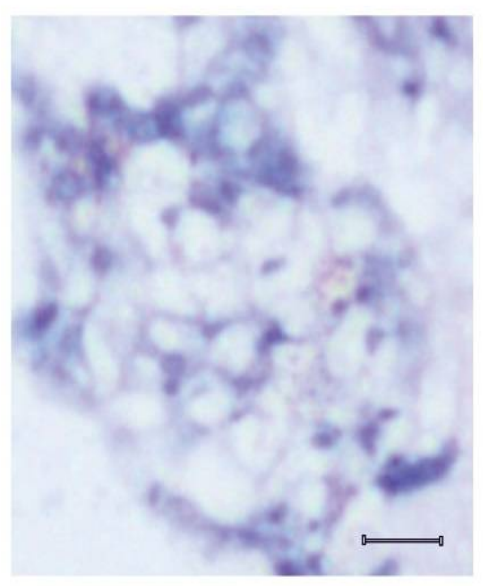

B

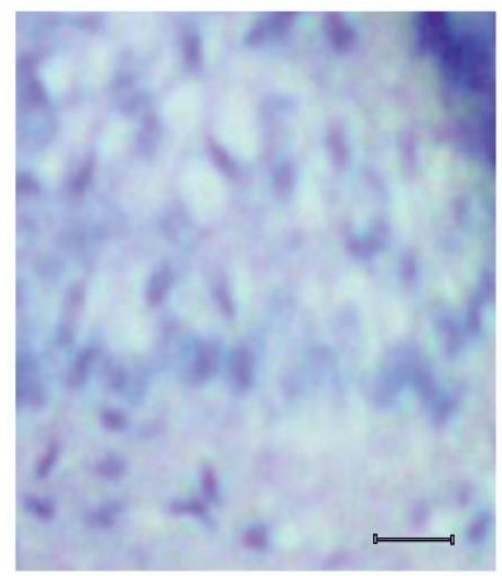

C

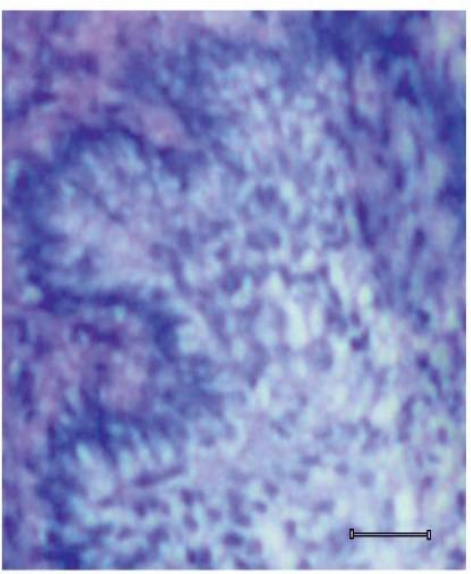

Figure 1: Mice model with low and high grade cervical cancer. A. Histological section of normal cervical tissue which shows regular arrangement of cells B. Histology of low grade cervical tumour with moderate cell proliferation. C. Histology of high grade cervical tumour with extreme cell proliferation. Scale Bar $=50 \mu \mathrm{m}$ size 
As the tumour progressed to a severe stage on the 8th week, the ALDH1 expression shows the maximum extent $(p<0.05)$. The study was further extended to find out the positive regulation of RKIP in tumour regulation. In the control tissue, the RKIP directs higher expression (Fig 2G) and acts as positive regulator that keeps check on the tumour progression. Interestingly, in the initial stage of the tumour, their expression gets up-regulated (Fig $2 \mathrm{H}$ ) but in the advanced stage of the tumour development, their expression gets down-regulated as expected ( $p$ $<0.05$ ) (Fig 2l).

\section{Western blotting results}

For better understanding of the correlation that the Sox2 expression has with ALDH1 and RKIP, the immunohistochemical data was further validated using western blotting analysis.
A

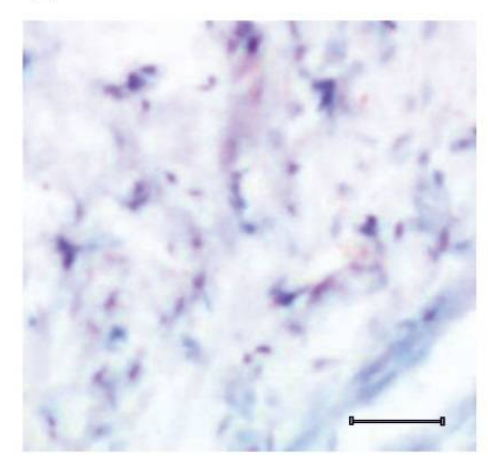

D

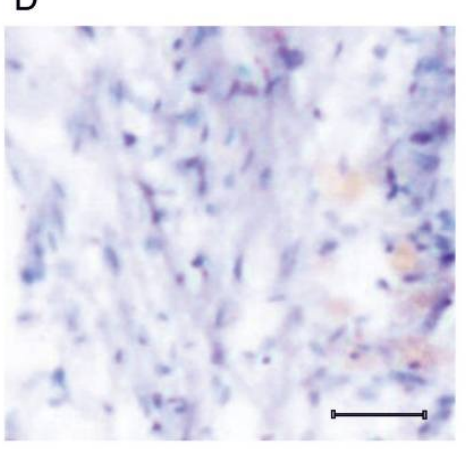

G

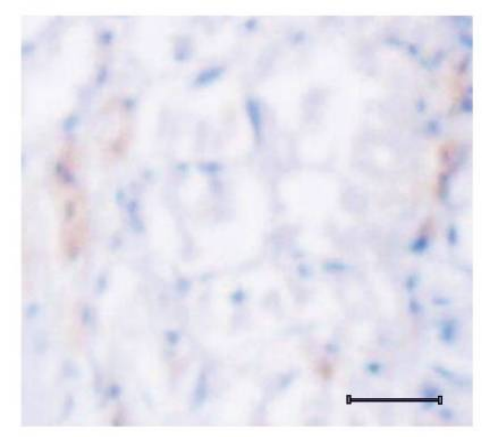

B

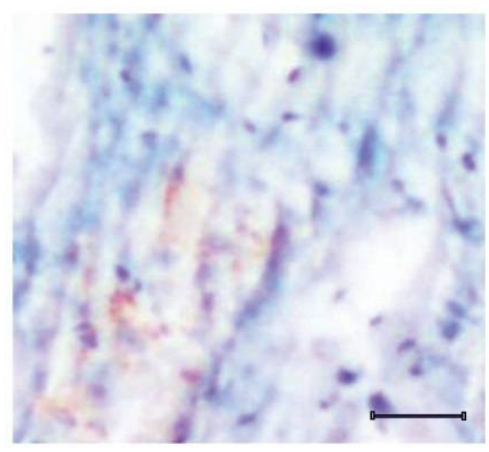

E

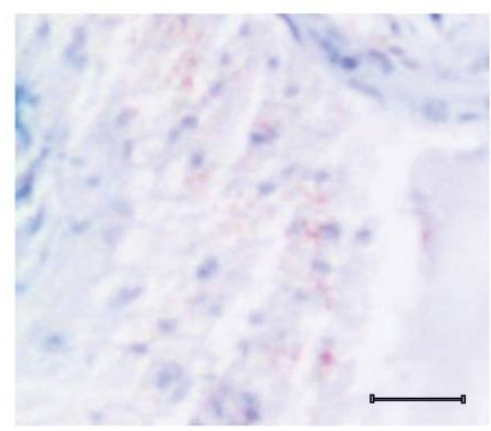

$\mathrm{H}$

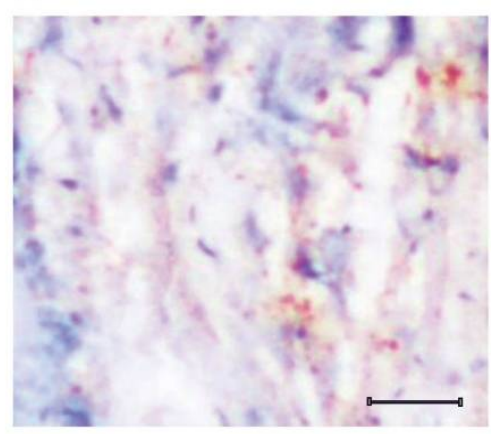

C

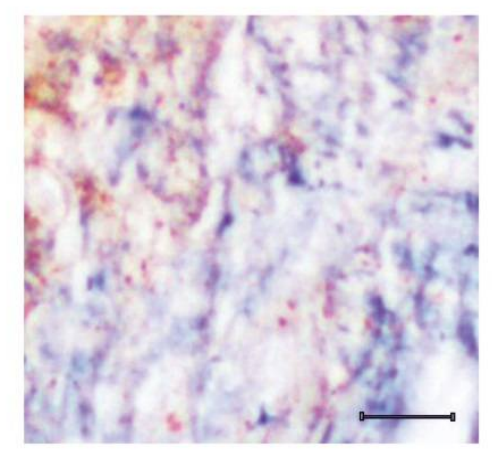

F

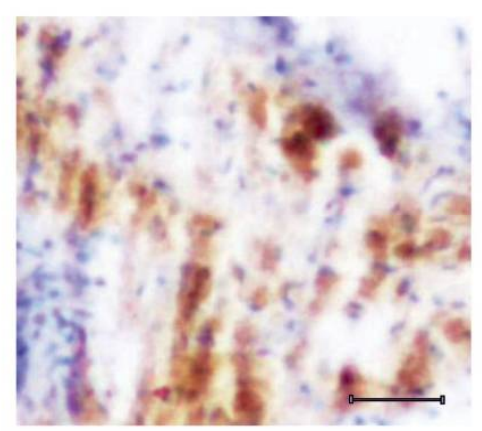

I

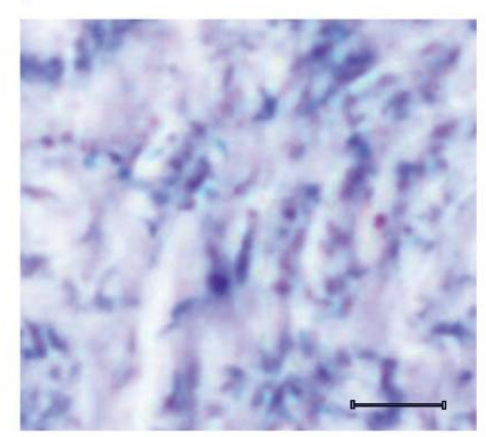

Figure 2: Upregulation of Sox2 expression correlate with ALDH1 and RKIP expression. A. Image represents the normal cervical tissue with less expression of Sox2 protein. B. Low grade cervical tumour shows mild expression of Sox2. C. High grade tumour with over expression of Sox2. D. Control tissue with little expression of ALDH1 protein. E. initial stage of cervical cancer with average expression pattern of ALDH1. F. advance stage of cervical cancer with more expression of ALDH1. G. Normal cervical tissue with moderate expression of RKIP. H. Low grade cervical tumour showing higher expression of RKIP protein. I. High grade tumour with little or no expression of RKIP protein. Scale Bar $=100 \mu \mathrm{m}$ size 

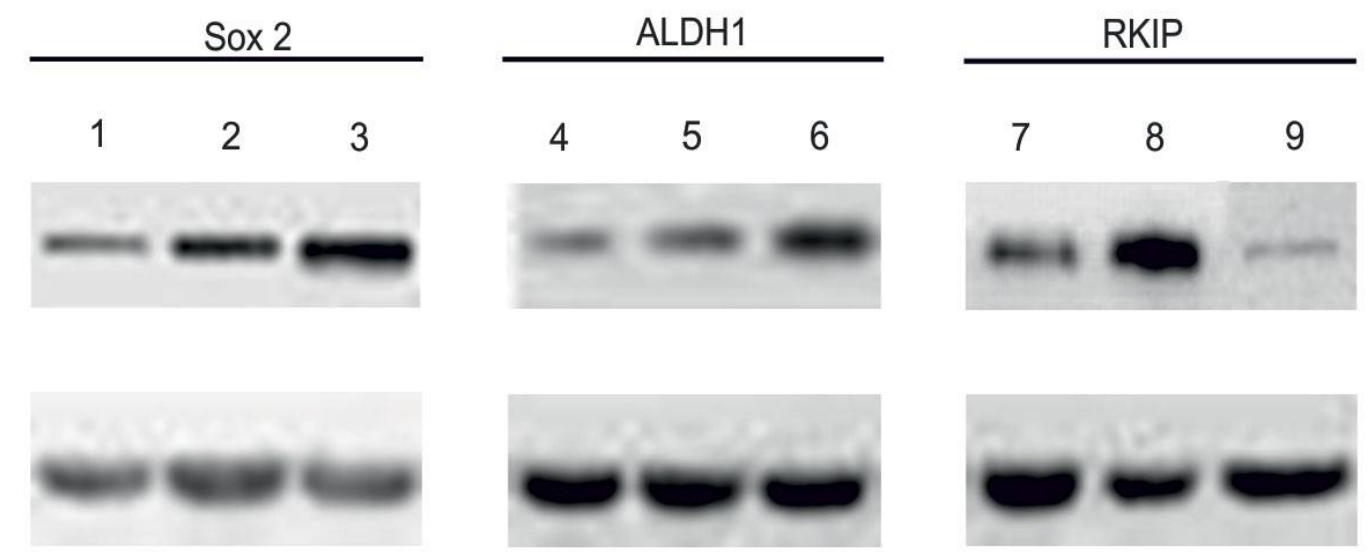

Figure 3: Validation of Sox2, ALDH1 and RKIP expression by western blot analysis. Lane 1 represents the Sox2 expression in normal cervical tissue. Lane 2 shows the Sox2 protein expression in low grade cervical tumour. Lane 3 specifies Sox2 protein expression in high grade cervical tumour. Lane 4 shows ALDH1 expression in normal cervical tissue. Lane 5 represents ALDH1 expression in initial cervical tumour. Lane 6 represents ALDH1 expression in high proliferative cervical tumour. Lane 7 represents the RKIP expression in normal cervical tissue. Lane 8 shows the RKIP protein expression in low grade cervical tumour. Lane 9 specifies RKIP protein expression in high grade cervical tumour. $\beta$-Actin was used as a loading control

The results with western blotting analysis demonstrate shows that the protein expression profile of Sox2 dramatically increased as the tumour progressed as shown in first three lanes of Fig 3. Similarly, increased the up regulated expression of ALDH1 with significant enhancement of ALDH1 expression in the advanced stage of the cervical cancer was noted as shown in lane four to six of Fig 3. But when compared with the control tissue, we observed that the RKIP expression showed elevated expression profile in the initial stage of the tumour and down-regulated latter in the advance stage of the tumour progression development as shown in lane seven to nine of Fig 3.

\section{DISCUSSION}

The connections between stem cell markers with different pathological conditions of cancer were still poorly investigated. Recently it was revealed that new stem cell markers emerged while studying the process of tumour initiation and progression [27]. The present study was carried out with a well-documented stemness associated marker named Sox2 [23]. Using this standard marker, we evaluated assess the expression of ALDH1 and RKIP which are less sensitive markers, in different in vivo pathological conditions.

In recent studies of prostate cancer, the expression of ALDH1 shows relatively lower expression instead of high expression, but the result with other isoforms of ALDH remains the same [28]. Thus the results with ALDH1 are needed to be validated further; especially in their in vivo condition. In our study, the mice model responded well in the tumour formation and it formed low grade as well as higher grade tumours (Fig $1 \mathrm{~B}, \mathrm{C}$ ) that helps to study the function of different proteins in tumour progression. The results obtained with an immunohistochemical against ALDH1, shows extensively high label proliferative cells in the advance stage of cervical cancer (Fig 2F) and the obtained result was consistent reliable with previously already reported data [12]. The higher the population of ALDH1 positive cells, the more revealed is their role in tumourigenicity and metastasis and their correlation is parallel with the cervical cancer stem cells that are identified using Sox2 (Fig 2A-C). The study of RKIP expression in various grade of tumour, reveals that in the initial stages of the tumour, the RKIP has a control over tumour development with higher expression (Fig $2 \mathrm{H}$ ), but at the higher grade of the tumour their control over the tumour was relaxed with lower expression (Fig 2I). Comparing the results along with Sox2, the higher expression upregulated profile of ALDH1 and lower expression of RKIP might also be involved in the pathogenesis of cervical cancer.

\section{CONCLUSION}

The expression pattern of ALDH1 and RKIP are tightly regulated in cancer stem cells in advanced stages of cervical cancer but they show disordered expression in initial stages of cervical cancer. 


\section{ACKNOWLEDGEMENT}

The authors sincerely thank all who supported this work.

\section{REFERENCES}

1. Minorics R, Bózsity N, Molnár J, Wölfling J, Mernyák E, Schneider G, Ocsovszki I, Zupkó I. A molecular understanding of $d$-homoestrone-induced G2/M cell cycle arrest in HeLa human cervical carcinoma cells. Journal of cellular and molecular medicine 2015;

2. Wang $X$, Tang S, Le S-Y, Lu R, Rader JS, Meyers C, Zheng Z-M. Aberrant expression of oncogenic and tumor-suppressive microRNAs in cervical cancer is required for cancer cell growth. PloS one 2008; 3: e2557.

3. Green JA, Kirwan JM, Tierney JF, Symonds $P$, Fresco $L$, Collingwood M, Williams CJ. Survival and recurrence after concomitant chemotherapy and radiotherapy for cancer of the uterine cervix: a systematic review and meta-analysis. The Lancet 2001; 358: 781-786.

4. Pectasides D, Kamposioras K, Papaxoinis G, Pectasides E. Chemotherapy for recurrent cervical cancer. Cancer treatment reviews 2008; 34: 603-613.

5. Ichim CV, Wells RA. First among equals: the cancer cell hierarchy. Leukemia \& lymphoma 2006; 47: 2017-2027.

6. Mao X-g, Guo G, Wang P, Zhang X, Xue X-y, Zhang W, Fei $Z$, Jiang $X$-f, Yan M. Maintenance of critical properties of brain tumor stem-like cells after cryopreservation. Cellular and molecular neurobiology 2010; 30: 775-786.

7. Su YJ, Lai HM, Chang YW, Chen GY, Lee JL. Direct reprogramming of stem cell properties in colon cancer cells by CD44. The EMBO journal 2011; 30: 3186-3199.

8. López J, Poitevin A, Mendoza-Martínez V, PérezPlasencia C, García-Carrancá A. Cancer-initiating cells derived from established cervical cell lines exhibit stemcell markers and increased radioresistance. BMC cancer 2012; 12: 48.

9. Storms RW, Trujillo AP, Springer JB, Shah L, Colvin OM, Ludeman SM, Smith $C$. Isolation of primitive human hematopoietic progenitors on the basis of aldehyde dehydrogenase activity. Proceedings of the National Academy of Sciences 1999; 96: 9118-9123.

10. Corti S, Locatelli F, Papadimitriou D, Donadoni $C$, Salani $S$, Del Bo R, Strazzer S, Bresolin N, Comi GP. Identification of a primitive brain-derived neural stem cell population based on aldehyde dehydrogenase activity. Stem cells 2006; 24: 975-985.

11. Charafe-Jauffret E, Ginestier C, lovino F, Tarpin C, Diebel M, Esterni B, Houvenaeghel G, Extra J-M, Bertucci $F$, Jacquemier J. Aldehyde dehydrogenase 1Positive cancer stem cells mediate metastasis and poor clinical outcome in inflammatory breast cancer. Clinical Cancer Research 2010; 16: 45-55.

12. Su Y, Qiu Q, Zhang X, Jiang Z, Leng Q, Liu Z, Stass SA, Jiang F. Aldehyde dehydrogenase 1 A1-positive cell population is enriched in tumor-initiating cells and associated with progression of bladder cancer. Cancer Epidemiology Biomarkers \& Prevention 2010; 19: 327337.

13. Stuelten $\mathrm{CH}$, Mertins $S D$, Busch Jl, Gowens M, Scudiero $D A$, Burkett MW, Hite KM, Alley $M$, Hollingshead $M$, Shoemaker RH. Complex display of putative tumor stem cell markers in the NCl60 tumor cell line panel. Stem cells 2010; 28: 649-660.

14. Fu Z, Smith PC, Zhang L, Rubin MA, Dunn RL, Yao Z, Keller ET. Effects of raf kinase inhibitor protein expression on suppression of prostate cancer metastasis. Journal of the National Cancer Institute 2003; 95: 878-889.

15. Minoo P, Zlobec I, Baker K, Tornillo L, Terracciano L, Jass JR, Lugli $A$. Loss of raf-1 kinase inhibitor protein expression is associated with tumor progression and metastasis in colorectal cancer. American journal of clinical pathology 2007; 127: 820-827.

16. Martinho O, Pinto F, Granja S, Miranda-Gonçalves V, Moreira MA, Ribeiro LF, di Loreto C, Rosner MR, Longatto-Filho A, Reis RM. RKIP inhibition in cervical cancer is associated with higher tumor aggressive behavior and resistance to cisplatin therapy. PloS one 2013; 8: e59104.

17. Al-Mulla F, Hagan S, Behbehani Al, Bitar MS, George SS, Going JJ, García JJC, Scott L, Fyfe N, Murray Gl. Raf kinase inhibitor protein expression in a survival analysis of colorectal cancer patients. Journal of Clinical Oncology 2006; 24: 5672-5679.

18. Maresch J, Birner P, Zakharinov M, Toumangelova-Uzeir $K$, Natchev S, Guentchev M. Additive effect on survival of Raf kinase inhibitor protein and signal transducer and activator of transcription 3 in high-grade glioma. Cancer 2011; 117: 2499-2504.

19. Olfert ED, Cross BM, McWilliam AA. Guide to the care and use of experimental animals. Canadian Council on Animal Care Ottawa, 1993.

20. Flurkey K, Currer J, Harrison D. The Mouse in Biomedical Research; Normative Biology, Husbandry, and Models. 2006;

21. Gefen A. Cellular and Biomolecular Mechanics and Mechanobiology. Springer, 2011.

22. Hamidouche Z, Haÿ E, Vaudin P, Charbord P, Schüle R, Marie PJ, Fromigué O. FHL2 mediates dexamethasoneinduced mesenchymal cell differentiation into osteoblasts by activating Wnt/ $\beta$-catenin signalingdependent Runx2 expression. The FASEB Journal 2008; 22: 3813-3822.

23. Ji J, Wei $X$, Wang Y. Embryonic stem cell markers Sox-2 and OCT4 expression and their correlation with WNT signal pathway in cervical squamous cell carcinoma. International journal of clinical and experimental pathology 2014; 7: 2470.

24. Leis O, Eguiara A, Lopez-Arribillaga E, Alberdi M, Hernandez-Garcia S, Elorriaga K, Pandiella A, Rezola $R$, Martin $A$. Sox2 expression in breast tumours and 
activation in breast cancer stem cells. Oncogene 2012; 31: 1354-1365.

25. Gangemi RMR, Griffero $F$, Marubbi D, Perera M, Capra MC, Malatesta P, Ravetti GL, Zona GL, Daga A, Corte G. SOX2 silencing in glioblastoma tumor-initiating cells causes stop of proliferation and loss of tumorigenicity. Stem cells 2009; 27: 40-48.

26. Basu-Roy U, Seo E, Ramanathapuram L, Rapp TB, Perry JA, Orkin SH, Mansukhani A, Basilico C. Sox2 maintains self-renewal of tumor-initiating cells in osteosarcomas. Oncogene 2012; 31: 2270-2282.
27. Li X, Wang J, Xu Z, Ahmad A, Li E, Wang Y, Qin S, Wang $Q$. Expression of sox2 and oct4 and their clinical significance in human non-small-cell lung cancer. International journal of molecular sciences 2012; 13 : 7663-7675.

28. van den Hoogen $C$, van der Horst $G$, Cheung $H$, Buijs JT, Lippitt JM, Guzmán-Ramírez N, Hamdy FC, Eaton CL, Thalmann GN, Cecchini MG. High aldehyde dehydrogenase activity identifies tumor-initiating and metastasis-initiating cells in human prostate cancer. Cancer research 2010; 70: 5163-5173. 